\title{
Authentic Family Learning: Reconceptualizing Intergenerational Education Initiatives in Jamaica and England Through Cross-Cultural Conversation
}

\author{
Charlotte Hardacre and Zoyah Kinkead-Clark
}

\begin{abstract}
Charlotte Hardacre is a lecturer in the Department of Health, Psychology, and Social Science at the University of Cumbria, where she has been a faculty member since 2014. She teaches a range of undergraduate modules on the Working with Children and Families degree program, with a focus on early childhood education and intergenerational learning. She is also a family learning practitioner, facilitating courses in primary schools in which children and adult family members learn together. Charlotte is conducting doctoral research in this field to understand the role of authenticity in family learning. Email: charlotte.hardacre@cumbria.ac.uk
\end{abstract}

Zoyah Kinkead-Clark is an early childhood lecturer at the University of the West Indies, Mona. She is keenly interested in how children are shaped by their experiences in the home and how educators build on these experiences in the classroom. She was a kindergarten teacher for several years, and her current research focus explores how young children, particularly those from lowresource regions, can be provided with greater opportunities to successfully meander the crucial first five years of life, especially in light of the significant challenges many of them face. Email: zoyah.kinkeadclark02@uwimona

This paper shares a set of cross-cultural conversations between two family learning practitioner-researchers, one from Jamaica and one from England. Our concern that global education policies reflect and reproduce a social investment perspective, positioning family learning as a way to generate productive citizens, drives this paper. Using Charlotte Hardacre's authentic family learning as a conceptual framework, we reexamine our ongoing work with families. An analysis of these cross-cultural conversations reveals that along with valuing the existing agency and identity of participants, there is also a need to balance the role of power enacted by practitioners; ultimately reconceptualizing power as a positive force that does not require inversion, minimization, or removal.

Key words: social investment; family learning; power; authentic learning

is constructed and how it may be reconstructed within our individual contexts.

Intergenerational learning has gained steady global acceptance as a tool to minimize dissonance among home, school, and community (Cartmel et al., 2018; Moriarty, 2001; Timmons \& Pelletier, 2014; Wainwright $\&$ Marandet, 2011). While the range of experiences covered in these family learning programs may differ, the overarching goals have often been to provide robust opportunities for collaboration, knowledge building, and strengthening of skills. In Jamaica and the UK, family learning programs have had a long history. The Jamaican Movement for the Advancement of Literacy (JAMAL), a family literacy program started in the mid 1970s to address the low levels of literacy across the island, and Families and Schools Together (FAST) in the UK serve as examples of two programs that have been very successful in yielding plethoric positive results (National Institute of Adult Continuing Education, 2013). This study analyzes a series of cross-cultural conversations between two researchers who are also practitioners who have been intimately involved in family learning programs. These conversations are structured around the six key practices of authentic family learning proposed intuitively by Charlotte Hardacre (2017). The process involved critical discourse to explore how intergenerational programming

\section{Context}

As noted above, both authors are practitioner-researchers who are currently involved with intergenerational learning activities. One of the authors (Zoyah) is the program manager for INSIGHTS into Children's Temperament (INSIGHTS) in Jamaica, an intervention which supports families in replacing harsh disciplinary 
practices with more responsive approaches. The other author (Charlotte) facilitates family learning courses in the UK, currently as an independent practitioner and previously, between 2009 and 2017, on behalf of a local council as a Family English, Maths, and Language (FEML) tutor. Through prior cross-cultural conversations about our practice (Kinkead-Clark \& Hardacre, 2017), we have uncovered clear differences between our contexts, including funding levels, social norms, and learning environments, while also discovering rich seams of similarity, such as the emphasis placed on intergenerational education in the early years as a way to ameliorate social problems including unemployment, adult literacy, and antisocial behaviour (Wainwright \& Marandet, 2017). To provide context for the analysis of our cross-cultural conversations, an outline of each of the intergenerational programs we are involved with is set out below.

\section{INSIGHTS in Jamaica}

INSIGHTS, in Jamaica, is a tripartite temperament-based program working with parents, teachers, and children. To date, INSIGHTS has been in 38 schools and has impacted 4,923 children, 327 adult family members, and 232 teachers in Kingston, St. Andrew, Manchester, St. Ann, and St. Catherine. Though the program predominantly targets children ages 4 to 5, within the past year the reach has been extended to children in grade 1 in primary school. The program has been in existence in Jamaica since 2013 and has the overarching goal to provide parents and teachers with behaviour management strategies and conflict resolution skills. Over the course of eight weeks, the program uses intergenerational sessions to help parents develop strategies that can be used to resolve challenging situations they encounter in the home environment. This provides them with an alternative that helps minimize their dependence on harsh disciplinary practices (beating, shouting, or cursing), which is a tremendous social issue in Jamaica (Bailey, Robinson, \& Coore-Desai, 2014).

\section{FEML in the UK}

Family English, Maths, and Language (FEML), in the UK, is a government-funded adult learning provision which is delivered by local authorities alongside a suite of other programs, including Personal and Community Development and Skills for Jobs (Leeds City Council, 2017). The family English courses delivered by Charlotte take place during the school day, in primary schools located in areas of high deprivation. The courses are between 8 and 10 weeks long and are attended by nursery or reception-age children and one or two of their adult family members. FEML courses are intended to reduce "the cost of supporting vulnerable families, through improved health and well-being, increased engagement with society, positive attitudes to learning, greater confidence and employability" (Learning and Work Institute, 2019, "Background," para. 3). FEML is therefore discretely political, as it addresses the needs of the employment market by "upskilling" adults. This functional approach to learning, which takes a narrow, vocational focus (Hamilton \& Burgess, 2011), sits in opposition to emancipatory ideals of education as liberatory and self-directed (Friedman, Kremer, Miguel, \& Thornton, 2011; Herz \& Sperling 2004; Levine, Lloyd, Greene, \& Grown, 2008), and it is the tension between these opposing perspectives that led to Charlotte's interest in authentic family learning (Hardacre, 2017) as an alternative approach. It is this approach that provides the conceptual framework for the cross-cultural conversations that were analyzed for this paper.

\section{Literature review}

As noted above, a working theory of authentic family learning is a touchstone for this paper. Thus, to deepen our understanding, we conducted a literature review that considers how an authentic approach to learning is characterized by socially contextual approaches, threatened by deficit perceptions of participants, and bolstered by creating a sense of belonging. 


\section{Socio-contextual learning}

Kristy Timmons and Janette Pelletier (2014) relate rigid and uncompromising approaches that privilege the needs of schools and marginalize the needs of families to deficit models of family support that maintain "a one-way transfer of knowledge, which often excludes parents' own knowledge and experiences" (p. 513). They argue, in line with Kerryn Dixon and Kelly Lewis (2008) and Elaine Rocha-Schmid (2010) that programs would meet the reallife needs more effectively if they took the diverse perspectives and practices of families more fully into account. Suggestions for addressing this deficit approach to intergenerational learning point to the benefits of developing a socio-contextual approach that is both family relevant and school relevant (B. L. Brown, 1998) and thus authentic and meaningful to all stakeholders.

Specific steps for moving toward a socio-contextual approach are articulated with much less frequency and detail in the extant literature, although some guiding principles are evidenced. For example, Janet Goodall and Caroline Montgomery (2014) suggest that immediate relationships and personalized knowledge of the participants provide a way to move toward more socially situated practice with families. This corresponds with dialogic approaches that are characterized by an interchange of values, ideas, and experiences in a two-way flow between stakeholders. Sara Lawrence-Lightfoot (2004) contrasts this sort of parental engagement, that is fluid, informal, and dialogue based, with the potentially superficial nature of highly ritualized school activities, such as parents' evenings.

A cautionary note about adopting a consultative approach is raised by Laurie Elish-Piper's (2000) study, which analyzed the social-contextual nature of adult education in urban family literacy programs: avoid tokenism. ElishPiper asserts that programs often use a dialogic approach to collect information about family strengths, needs, and goals, but do not use these details to inform the content or structure of courses. This point is developed by Donald Simpson and Mark Cieslik (2002), whose research outlines how optimistic initiatives to include participant voice in the development of programs can collapse in practice because of assumptions about parents' level of skill and confidence and the amount of trust they have in practitioners and programs.

This perspective is advanced by Karen Argent (2007), who discusses how parents' role in collaborative projects is unintentionally diminished by practitioners who privilege professional knowledge through repeated reference to official processes that lack relevance to parents. A similar point is described by M. C. Black (2007), who underscores the importance of conversing with parents without using jargon because of its potential to push them away. Correspondingly, Julia Bryan and Lynette Henry (2012) call on practitioners who are working with families to:

purposefully diminish their roles as the "experts," respect families' knowledge and insight, regard each other as valuable resources and assets, involve family members in mutual and equitable decisions about partnerships goals, activities and outcomes, refuse to blame each other and encourage families and communities to define issues. (p. 410)

This approach has the potential to build what Anthony Bryk and Barbara Schneider (2002) call "relational trust," which may be lacking between educators and parents who have had poor prior experiences of education, meaning it is hard for either party to understand the motivation or actions of the other. Arguably, emphasizing the importance of learning the differences and similarities between each other's values and beliefs is a practical form of critical pedagogy that has the potential to prompt practitioners to "consider their own identities and contexts, not just those of the community members" (Ashworth \& Bourelle, 2014, p. 64), eventually moving both parties toward more authentic forms of interaction. 


\section{Deficit perceptions}

Several sources in the literature under review here describe how a return to learning in a primary school setting can be a barrier for participants in family learning (Brassett-Grundy, 2001; Kwan \& Wong, 2016; Lexmond, Bazalgette, \& Margo, 2011; Moriarty, 2001; Wainwright \& Marandet, 2017; West, 2005). Angela Brassett-Grundy (2001) surveyed nonparticipating parents to find out why they chose not to engage in an intergenerational learning program and found a common reason was a previous unhappy experience of learning at school and concern about entering a formal educational space. Similarly, a survey by Peter Hannon and Viv Bird (2004) found that low levels of confidence and comfort in educational settings were powerful barriers to engaging in family learning.

Additionally, unease is evident in the literature about recruiting parents to intergenerational learning programs solely to apply normative ideals about appropriate ways of supporting children's needs (Argent, 2007; Wainwright \& Marandet, 2013). The consequences of this are apparent in Bryan and Henry's (2012) study; they point out that "educator attitudes about families and partnerships determine how [educators] treat families and partnerships" (p. 414), suggesting that programs that seek to identify and then improve particular "types" of parents may be rooted in patronizing, pessimistic, or disapproving attitudes, which are unlikely to be explicit but will shape interactions between participant and practitioner. This makes the argument for consciously working to understand differences as opposed to assumptively labelling practices and perceptions that differ from our own as deficient.

Emma Wainwright and Elodie Marandet (2017) argue that judgmental attitudes about the way families function reflect and reinforce the "professionalization of parenting as a set of skills to be taught, understood and practised" (p. 214). Additionally, the use of schools as a space for enacting public policy is a matter of concern for scholars such as Kwan and Wong (2016), who suggest that because schools are arguably a middle-class institution, with norms that may differ from other socioeconomic groupings, it becomes a foregone conclusion that disadvantage and negative parenting practices are inextricably linked, a claim addressed by Lexmond, Bazalgette, and Margo (2011), who undertook qualitative research in an area with high levels of deprivation, unemployment, and crime in Glasgow. Lexmond and colleagues found a key feature of daily life "was the presence of familiar and trusted family friends and neighbours, and open communication and trust between parents and children" (p. 87), disrupting the idea that parenting problems are widespread in areas experiencing poverty, a stagnant labour market, and criminality.

There was extensive recognition across the literature of the idea that family learning is often rooted in pathologized or deficit perceptions of families (Elish-Piper, 2000; Harris \& Goodall, 2008; Heydon \& Reilly, 2007; Luguetti \& Oliver, 2017; Moriarty, 2001; Timmons \& Pelletier, 2014). In fact, Elish-Piper (2000) called nearly two decades ago for a move from deficit models of family literacy programs aimed at perceived weaknesses toward strengthsbased approaches, and this call still echoes in more recent work by Wainwright and Marandet in 2013 and 2017. In the latter, concerns are raised about practitioners casting "a web of inspection and judgement" (Wainwright \& Marandet, 2013, p. 20) in order to recruit parents who are unemployed or have low levels of education to family learning courses so that the social and economic policy interests of the government can be served as opposed to the authentic interests of parents.

Sense of belonging

Developing a distinct space for intergenerational learning was raised in a number of sources as a way to tackle a disconnect between parents and settings where family learning classes take place. This is an important solution because, as noted by Dolores Loughrey and Caroline Woods (2010), such divides can lead families to "view schools with mistrust and suspicion and ... not see education as having much to do with their everyday lives" (p. 82). 
Creating a welcoming and comfortable environment is a facet of building trust and demonstrating the value a school places on the role of parents. Penny Lamb (2009) documents a concerning disregard for the way family learning courses are delivered in primary schools in the UK, noting:

Examples include classes taking place in corners of the staff room with constant interruptions; inappropriate furniture to meet the needs of adults; and courses cancelled because schools require children to be involved in an activity that is seen as a greater priority. (p. 8)

Kate Pahl and Sally Kelly (2005) suggest that the place created by family learning groups can be understood as a "third space between home and school offering parents and children discursive opportunities drawing on both domains" (p. 91). Liz Heydon and Jill Reilly (2007) also use third space thinking to describe how family learning might increase "the value attributed to home activity at school and school activity at home" (p. 157), a suggestion reminiscent of Joyce Epstein's (2010) widely cited call for family-like schools and school-like families, or the creation of a bridging space between home and school where schools take on a nurturing and inclusive nature and families reinforce the value of homework, classroom norms, and high engagement with learning.

A challenge an authentic practitioner would face, however, is developing truly meaningful activities, as opposed to those mandated by the school (Barillas, 2000; Sangster, Stone, \& Anderson, 2013). Maria del Rosario Barillas (2000) tackled this challenge by setting out the characteristics of meaningful activities prior to embarking on her intervention. These included the activity reflecting the families' cultural practices, having a personal element, and being relevant beyond the classroom. Another useful definition was framed by Elsa Auerbach (1989), who drew on Paulo Freire's (1970) work to argue that an activity is meaningful "to the extent that it relates to daily realities and helps [people] to act on them" (p. 166). This definition links meaning with context and indicates that acting authentically requires practitioners to engage with parents' everyday lives and avoid imposing school norms on them. This sort of guidance is useful, but is somewhat limited across the literature reviewed here, and thus a gap has been identified wherein a wide range of scholars describe the nature and benefits of authenticity in learning, but far fewer delineate specific steps for developing authentic practice This study will go some way to addressing this gap by interrogating, as part of a wider set of aims, a specific set of practices that could be followed to achieve an authentic approach to family learning.

\section{A journey to authentic family learning}

The authentic family learning approach emerged from a tension between Charlotte's personal values and the professional and political expectations that acted on her in the role of FEML tutor (e.g., the mandatory requirement by the local authority to improve parents' employability, literacy, and numeracy levels when they were recruited to attend a family learning course in their child's school, whether they had expressed an interest in this goal or not). The marketing of these courses emphasized spending time with children over the employability and literacy activities. This drive, which was part of the Skills for Life strategy launched in 2001, also encompassed the mandatory use of decontextualized, mass-produced learning materials that lacked relevance to adult participants' everyday lives. For example, parents found the experience of completing cloze exercises (i.e., filling in the blanks) based on working in a call centre, or adding punctuation to paragraphs of text about country fairs, disheartening and demotivating, particularly when time devoted to these activities detracted from the amount of time the children would spend in the classroom (Hardacre, 2011).

The term authentic family learning was chosen because Charlotte has developed practice, within the FEML context, which involves using materials and activities that are not solely designed for use in school. There are reallife purposes for the practices, and these are arrived at through dialogue and consultation with the parents and 
children involved in the course. For example, in one setting this involved planning, raising funds for, executing, and celebrating an educational visit to an indoor ski slope. The vast range of discrete literacy tasks within this shared activity were all real. This task included the parents' interests, a considerable number of meaningful choices, and the parents carrying out the actions, with purpose, in order to complete the task. This type of approach has been referred to as authentic learning by a wide range of scholars, including Jacobson, Degener, and Purcell-Gates (2003), Maina (2004), Lombardi (2007), and Hui and Koplin (2011).

Thus, it was as a result of concerns about homogenous and decontextualized approaches to FEML that authentic family learning emerged as an approximated and best-fit approach wherein Charlotte worked to meet the disparate agendas of funder, practitioner, participant, and setting. Consequently, the use of unorthodox and unsanctioned methods of working with families who had not volunteered to be "upskilled" were conceptualized as six key practices (see Figure 1) that encapsulate Charlotte's approach to setting up and delivering family learning in a way that is congruent with critical pedagogical values and authentic learning practices. These practices, outlined in Table 1 below, shape Charlotte's concept of intergenerational learning and have been selected as the basis for cross-cultural conversations with Zoyah. The conversations explored areas of resonance and dissonance with these practices in order to reconceptualize our understanding of intergenerational learning,

\section{Authentic \\ Authentic \\ Authentic \\ Authentic \\ Authentic \\ Authentic \\ Lifeworlds \\ Place \\ Agendas \\ Actions \\ Relating \\ Reflection}

Figure 1. The six key practices of authentic family learning. 
Table 1: The Six Key Practices of Authentic Family Learning

\begin{tabular}{|c|c|}
\hline Authentic lifeworlds & $\begin{array}{l}\text { The lifeworld (Habermas, 1987) encompasses a wide range of } \\
\text { conventions and suppositions about "who we are as people and } \\
\text { what we value about ourselves: what we believe, what shocks and } \\
\text { offends us, what we aspire to, what we desire and what we are } \\
\text { willing to sacrifice" (Frank, 2000, para. 16). In authentic family } \\
\text { learning, none of these lifeworlds is privileged above another, } \\
\text { although power is disproportionately allocated and therefore } \\
\text { always relevant and impactful. }\end{array}$ \\
\hline Authentic place & $\begin{array}{l}\text { The authentic practitioner recognizes the potential for parents } \\
\text { feeling they are in a hostile environment and seeks to create a } \\
\text { "third space" that is distinct from home and school (Pahl \& Kelly, } \\
\text { 2005). Seemingly small actions, such as insisting on appropriate } \\
\text { rooms with adult-size furniture, disrupt the conventions of family } \\
\text { learning courses and set an authentic tone that prioritizes the } \\
\text { immediate experiences of the people involved. }\end{array}$ \\
\hline Authentic agendas & $\begin{array}{l}\text { Establishing shared goals focused on real tasks is therefore the most } \\
\text { fundamental aspect of authentic family learning, especially given } \\
\text { that many families have experienced deficit-based interventions } \\
\text { where they were told what is wrong with them. The authentic } \\
\text { practitioner will need to establish trust and build constructive } \\
\text { relationships with families in order to agree on a shared goal that } \\
\text { works for everyone. }\end{array}$ \\
\hline Authentic actions & $\begin{array}{l}\text { Activities in FEML programs are often abstract, decontextualized, } \\
\text { and prescribed in advance. In contrast, authentic activities are } \\
\text { grounded in the lives of the families and involve practitioners and } \\
\text { parents co-planning meaningful activities. This can only happen } \\
\text { when agendas are explicit and authentic, as these create the } \\
\text { boundaries for the choice of actions available to the whole group. }\end{array}$ \\
\hline Authentic relating & $\begin{array}{l}\text { The roles of trust and reciprocity are significant in this practice. } \\
\text { The lack of hierarchy and imposed activity can create suspicion } \\
\text { and confusion, while the accepted roles of teacher and student } \\
\text { are not being taken up, creating a period of negotiation and, in } \\
\text { some cases, boundary testing. During this phase the practitioner } \\
\text { should maintain a focus on the shared goal and the enjoyment and } \\
\text { engagement with the children. }\end{array}$ \\
\hline Authentic reflection & $\begin{array}{l}\text { Authentic family learning (AFL) will never take a static form; } \\
\text { it will require constant negotiation and adjustment, a form of } \\
\text { steering and control by the practitioner which some may feel } \\
\text { belies authenticity, but is in fact the hallmark of AFL. Adults and } \\
\text { children participating in AFL are invited to acknowledge and } \\
\text { critique power structures through reflection on the impact of these } \\
\text { on their own agency. }\end{array}$ \\
\hline
\end{tabular}




\section{Methodology}

This study is part of a wider set of research in which, as two researchers from different contexts, we engaged in a series of cross-cultural conversations to discuss critical issues relating to intergenerational learning in our respective countries. As suggested by Suhonen, Saarikoski, and Leino-Kilpi (2009), cross-cultural research provides a robust opportunity to advance knowledge by taking a global perspective on critical issues. Likewise, as proposed by Oluwatoyin Ilesanmi (2009), cross-cultural research ultimately seeks to remove barriers and bias in research by acknowledging cultural differences while simultaneously reaffirming global similarities.

Cross-cultural approaches are a useful response to ethnocentric discourses (Beiser, 2003; Sullivan \& Cottone, 2010) because of their potential to contextualize researcher interpretations and situate knowledge within local communities. This possibility is demonstrated in a study by Widenfelt et al. (2005) which found that ethnocentric definitions of social competence for children resulted in bias and inaccurate conclusions because of the differing, culturally situated meanings attached to the term. This finding indicates one way in which a cross-cultural approach may help researchers "to reconsider conceptualisations that appear to be universal yet are actually based in Western standards and perspective" (Sullivan \& Cottone, 2010, p. 360).

Guided by this aim, we employed naturalistic collaborative enquiry as our methodology (Burnard et al., 2006), specifically in the form of a series of cross-cultural conversations in which we sought to reappraise our initial understandings of the purposes and practices of intergenerational learning. As Neil Haigh (2005) explains, because "conversation is a constant in our personal and professional lives, we are not necessarily inclined to think about it as a research tool" (p. 3). However, in line with Senge (1994), Baker, Kolb, and Jensen (2002), and Burnard et al. (2006), we position conversation as a valuable context for learning. In doing so, we acknowledge the distinct nature of conversation and the competencies and sensitivities that are required if conversation is to become an occasion for learning. Specifically, we contend that our cross-cultural conversations, as expressed by both Haigh (2005) and Senge (1994), should balance inquiry and advocacy, meaning that participants should both state and justify their initial position while also engaging in an exploration and "critique of the reasons and assumptions associated with their positions" (Haigh, 2005, p. 8).

Thus, conversation has the potential to be a purposeful yet intuitive exploration of extant positions in a dialogue enhanced by distinct features such as "immediacy, personal relevance, rich stories, serendipity, improvisation, an open agenda, permissiveness, and risk-taking" (Haigh, 2005, p. 14) which may be found less often in other interactions for research, such as structured interviews or oral surveys. Therefore, we sought to use conversation to identify and document our concepts of intergenerational learning by utilizing Charlotte's six key practices of authentic family learning (Hardacre, 2017) as categories to discuss one by one.

\section{Researcher positionality}

Table 2 below compares the Jamaican and UK contexts on a number of factors. 
Table 2. Jamaican and UK Research Contexts

\begin{tabular}{l|l}
\hline Jamaican Practitioner Researcher: Zoyah & \multicolumn{1}{l}{ British Practitioner Researcher: Charlotte } \\
\hline $\begin{array}{l}\text { Project manager } \\
\begin{array}{l}\text { Program caters to parents, teachers, and } \\
\text { children }\end{array}\end{array}$ & Facilitator \\
\hline $\begin{array}{l}\text { Predominantly involves inner-city schools in } \\
\text { Kingston, St. Andrew, and St. Catherine }\end{array}$ & $\begin{array}{l}\text { Predominantly involves schools high on } \\
\text { deprivation index in northwest England }\end{array}$ \\
\hline $\begin{array}{l}\text { Program caters to children 5-6 years old } \\
\text { Responsibilities in the program include } \\
\text { tracking parent outcomes, teachers' classroom } \\
\text { practices }\end{array}$ & $\begin{array}{l}\text { Caters to children 0-5 } \\
\text { supporting employability of parents and } \\
\text { improving children's literacy skills }\end{array}$ \\
\hline
\end{tabular}

\section{Data collection}

The data gathered for this research was garnered through comparative cross-cultural methodology. This method was purposefully selected because it provides an opportunity to remove boundaries and other limitations on how "knowing" is constructed. Likewise, as suggested by Junko Tanaka-Matsumi (2001), cross-cultural research provides an opportunity for researchers to interrogate the similarities and differences across and between cultures. By presenting an emic perspective on our individual experiences with family learning programs, we engaged in a series of cross-cultural conversations. We were able to examine each other's contexts, life experiences, and perspectives in order to interrogate and compare our individual concepts of family learning within our own contexts.

To gather these data, we engaged in approximately 12 hours of conversations via Skype over the course of ten meetings. As previously stated, our conversations about family learning were explored in relation to Charlotte's six key practices (Hardacre, 2017). We selected this as a framework to find resonance or dissonance with our respective concepts of intergenerational learning. Throughout each conversation, we both took notes of statements, points, or topics which we felt were particularly important or significant (Hermanowicz, 2002; Wolfinger, 2002). At the end of every conversation, we each undertook a general overview of the notes taken. This practice served two purposes. It first provided us with the opportunity to appraise each other of the points we individually felt were important; second, it allowed us to clarify issues which we individually felt needed to be elaborated or expanded on.

To analyze the data, we used deductive thematic analysis because, as suggested by Braun and Clark (2006), this method provides a basis for using a previously developed theory to determine how resonant or dissonant the findings from previous research are. In this case, we used Charlotte's six key practices of authentic family learning. To do this, we perused the data collected throughout our conversations and then sought to assess how well they aligned with Charlotte's categories (Hardacre, 2017). The suitability and the alignment are discussed below.

\section{Findings: Reconceptualizing through resonance and dissonance}

Following the analysis of our cross-cultural conversations, a range of resonant and dissonant factors emerged. In relation to authentic lifeworlds, both practitioner-researchers acknowledged that parents attending their intergenerational learning programs come from diverse circumstances and bring their experiences and worldviews into the learning space. Zoyah noted, "These experiences should be valued even if they counter the philosophical 
underpinnings of the course." This shared perspective was shaped by the fact that both interlocutors facilitate programs that take a social investment perspective which may connote normative ideas about appropriate or good parenting that do not align with the beliefs or understandings of participants. The conversations revealed the mutual perspective that effective practice can only begin once participants and facilitators have developed a reciprocal respect for each other and the learning process. We both expressed the ways that this could be challenging because of the disproportionate allocation of power between facilitator and families. As a result, we both expressed a desire to convey equal value to all participants and make efforts to tackle difficulties up front. Charlotte noted the need to be cognisant of her power to legitimize the beliefs, values, actions, and judgements of the group. Zoyah echoed this point, while also pointing out the challenge of training other facilitators to understand the implicit ways they might impose their power on the groups they are leading.

A particularly rich area of resonance was evident in relation to the concept of authentic place. This was revealed when the practitioner-researchers referred to the physical space allocated to family learning in a school or setting, connoting a level of valuing and respect for families. Zoyah explained, "In many instances, schools provide a space that reflects little consideration of the parents' comfort ... It is not uncommon for programs to be held in rooms primarily used for storage." Both practitioners related the common experience of their courses being located in inappropriate spaces, despite lengthy negotiations to set up the course, with some schools perceiving intergenerational learning as an afterthought or bolt-on to the central activities of the school day. Mitigating factors, such as availability of space within the school, timetabling issues, and availability of staff cannot be dismissed but do not wholly account for the seemingly low status attributed to families attending classes in box rooms, storage areas, or thoroughfares. This reinforcement of the hierarchical relationship between school and family is power laden, as the parent has limited recourse to make changes to the situation. This positions the family learning facilitator in a unique position to redress this power imbalance, but it raises questions about when this is the appropriate stance to take.

In terms of authentic agendas, resonance was found between the interlocutors in terms of developing a shared understanding about the nature and purpose of the course. This was particularly important to the practitionerresearchers because of the instructive and corrective nature of intergenerational learning that comes from a social investment perspective. INSIGHTS helps parents reduce their reliance on harsh disciplinary practices and FEML aims to improve literacy and employability, thus both practitioner-researchers felt a strong drive to ensure parents were fully aware of these aims, and both rejected well-intended but ultimately deceptive approaches, such as suggesting the sessions are simply an opportunity to work alongside their child at school. Again, our conversation turned to the role of power, with Zoyah pointing out the structural factors that may have led parents to be enrolled in her program in the first place, such as being compelled by the state to undertake parenting classes with their child.

In terms of authentic actions, an analysis of the conversations revealed some dissonance within this practice. When discussing the use of authentic materials in sessions, Zoyah noted that because INSIGHTS is a program that has been adapted from the US, many of the "resources used throughout the program reflect a context quite dissimilar to Jamaica." Redesigning these resources would be too costly and time consuming, so the Jamaican facilitators of the program actively highlight the similarities and differences to stimulate discussion germane to the lived experiences of the participants. This best-fit approach was a common experience for Zoyah, who noted that an expectation to use techniques and resources based on imported Euro-American ideas of best practice, was part of her daily reality.

Thus, practical and material factors clearly shape the degree to which a practitioner can be guided by the concept of 
authentic actions. Charlotte also noted that "using authentic materials can be challenging on short courses, as there is limited time to get to know parents and design activities around their interests." On these occasions, Charlotte explained that she would focus on a shared project that could be personalized, such as making "story sacks." Here, each family group could select their own book to base their "story sack" on, but the activities each week could be planned without parental input and contextualized week to week. For example, week two would involve the families creating a puppet based on their personally chosen story. In both instances, the practitioner-researchers did not eschew the idea of authenticity - which we define in line with Jacobson et al. (2003) as approaches that are relevant, meaningful, and personal-but we did have to adapt in line with financial and temporal realities. This indicates that the six key practices of authentic family learning are best understood as guiding principles to be led by, rather than prescriptive rules to apply in a wholesale and rigid manner.

The conversations also revealed that an adaptive approach resonated with the concept of authentic relating. For example, Zoyah explained that families were more likely to engage with and complete the course when there was a shared understanding about the purpose of the program. Developing this shared understanding is of course heavily reliant on a responsive relationship between stakeholders. Both researcher-practitioners emphasized the importance of honest and open communication among participants, practitioner, and setting. This was not seen as a straightforward task, as the differing interests of, for example, schools and families can put pressure on facilitators to act as an intermediary. Both of us agreed that rejecting this role was the most effective strategy, as we invariably both experienced what Charlotte referred to as "trying to please everyone and ultimately pleasing no one ... It's not effective to advocate for both groups at the same time. You have to get them to talk to each other." Again, we observed in our conversation our function in shifting and redistributing the power operating between the stakeholders, with Zoyah questioning whether this role should be more explicitly acknowledged in the design of intergenerational learning programs and in the courses that train the facilitators of such programs.

Resonance also emerged in relation to the last of the six key practices of authentic family learning: authentic reflection. Both practitioners could see how this process aligns with the pursuit of critical consciousness, in which power structures are revealed. Charlotte recounted the ways in which she might invite participants to acknowledge and critique these structures and reflect on their impact on their own agency. However, as Zoyah pointed out, while this may involve parents questioning the legitimacy of authority figures in the school, it should not devolve into a generalized and circular airing of grievances. Charlotte agreed that mindful and focused facilitation of these types of discussions is essential. This conversation revealed the power-laden steering role practitioners may play within intergenerational learning programs, including those with emancipatory aims.

Additionally, our analysis revealed resonance with authentic reflection when Zoyah brought up how "subtle biases and discourses surrounding the participants of such programs ... may be shared by stakeholders within the school walls" and suggested the need to allow time to recognize and seek ways to address these through critical reflection. Charlotte agreed, noting that family learning tutors are often accepted as a natural peer by teaching staff and thus included in staffroom gossip or well-intentioned but denigrating narratives about the challenging lives of parents and children in the school. The conversation turned to how taking a buffering role between the competing interests and agendas of staff and parents can have merit, but that the practitioner may face the temptation to placate both sides. While doing so, at face value, could appear to simply be abiding by social norms of empathy and polite agreement, our conversation revealed a feeling that it would in fact be a form of collusion that maintains the status quo between the two groups. Therefore, actively choosing to challenge deficit discourses about parents and to reframe criticisms of the teachers and school toward solutions and action was seen as the best use of the unique and powerful position the intergenerational educators can find themselves in. 


\section{Discussion: Reconceptualizing power in intergenerational learning}

By engaging in cross-cultural conversations, using authentic family learning as a conceptual framework, we found much common ground between the UK and Jamaican contexts. This can be attributed partly to the fact that we both deliver intergenerational programming that is underpinned by a social investment approach. The corrective and instructive nature of such programs is hierarchical and power laden, and this power operates at various levels (Holloway, Brown \& Pimlott-Wilson, 2011; McDowell, 2004; Raco, 2009). The negotiation and management of power in our different contexts shaped our entire set of cross-cultural conversations and leads us now to reconceptualize our understanding of the role of power in relation to practitioners and participants. As a result of this reconceptualization, we argue for a need to balance rather than subvert, invert, or remove existing power positions in intergenerational programs.

We were both aware of the influence of global policies on driving implementation and uptake of intergenerational programming in both our contexts. For example, the United Nations' sustainable development goals emphasize education as "intrinsically an intergenerational process" (Bengtsson \& Barakat, 2016, p. 5) and call for an increase in family learning programs as a way to minimize the intergenerational transmission of poverty. We also recognized that as a consequence of these global priorities, local authorities target families who are "considered most deviant in terms of economic and social norms" (Wainwright \& Marandet, 2017, p. 215) for recruitment into intergenerational learning programs with social investment aims. However, our conversations revealed concern about governmentality and the more "coercive and regulatory dimensions" of intergenerational programs (Wainwright \& Marandet, 2013, p. 3), but lacked any insight into how to address such concerns practically.

Following the analysis of our conversations we considered how, in the everyday life of our classrooms, we accounted for this corralling of specific types of families into intergenerational learning programs that seek to "upskill" them and build aspirations that fit with "highly normative forms of identity" (Wainwright \& Marandet, 2017, p. 226), particularly those with low levels of education who are not employed and who live in areas of high deprivation. We identified that a key approach we already utilized intuitively was to actively discuss the purpose of the course with the families involved in such programs. We see this as a practical way to balance power because it moves a previously hidden agenda into the light. Entering into dialogue with participants about what drives the funding and framing of intergenerational programs is in line with Freire's (1970) argument that it is "in speaking their word that people, by naming the world, transform it" (p. 45).

This form of transformative dialogue, in which the nature and purpose of the course is actively acknowledged and engaged with by participants, is a way to ensure that the learning is grounded in participants' existing "agency, identities and literacies" (A. Brown, 2011, p. 3), allowing them to make sense of their experiences and to raise their critical consciousness about the interests and agendas being enacted through the intergenerational program of which they are a part. This dialogue can infuse and shape the course, but it is not the central focus of the program, and thus it takes the form of informal and spontaneous conversations about the families' reasons for attending or the purpose of activities. Allowing questioning to be an acceptable and welcome form of dialogue is a practical way to balance the distribution of power in intergenerational learning.

Prior to our cross-cultural conversations, we both characterized our practice as learner centered, but the process of unpacking the lived experience of delivering intergenerational programming revealed that achieving learnercentered practice often requires significant intervention from practitioners to draw out families' interests, beliefs, and values. This may well take place while working to externally set timescales, using decontextualized materials in spaces not designed for learning. When the practitioner is necessarily expending control to create a learnercentered experience, it would be disingenuous to claim that power structures are equalized or flattened. This is 
in line with Michele Schweisfurth's (2014) call for the discourse on learner-centered pedagogy to account for the role of the practitioner more fully. Schweisfurth acknowledges that learner-centered approaches, in practice, often feature teacher authority or curricula prescription because programs are always "deeply embedded in the cultural, resource, institutional and policy contexts in which they take place" (p. 259).

This insight has much in common with the work Wainwright and Marandet (2013), who explicitly tackle power in family learning by suggesting that the relational dimensions of family learning, such as the broadening of social networks or the rapport between tutor and parent, are not simply an outcome of participation but are also "an important strategy through which family learning is effectively mobilised" (p. 22). This Foucauldian (1991) reading conceptualizes the power that operates through family learning as positive or supportive, and acknowledges that "relationships of empowerment are both voluntary and coercive, simultaneously controlling and liberating" (Wainwright \& Marandet, 2013, p. 28) in ways that neutral articulations of the interactions between participants and practitioners taking part in intergenerational learning obscure.

This characterization of "supportive power" aligns with our experience of the benefits of a relational approach to family learning, such as improved retention rates and the continuation of family learning groups beyond the duration of the course itself. It also allows issues of control, influence, and authority to be recognized and held in tension with a more positive reading of the role of power. This is in line with Carol Vincent and Simon Warren's (1998) point that intergenerational learning programs that have a social investment focus are never entirely oppressive or entirely liberatory, and "it is only by recognising and holding these opposing readings in tension that an analysis can be formed which appreciates both" (p. 191).

\section{Knowledge democracy}

It should be noted that our dialogue is grounded in our positional contexts, with Charlotte working in a context that reflects Eurocentric models of "best practice" and Zoyah in a context that frequently measures itself against these Eurocentric models (Rao et al., 2014). Thus, the use of a conceptual framework rooted in British practice should be noted for its dominant-hegemonic perspective. Our awareness of the importance and value of knowledge democracy (Hall, 2014) meant we acknowledged this perspective through our cross-cultural conversations with the hope of destabilizing commonly assumed "positions of power."

This acknowledgement resonates with the work of Levermore and Beacom (2009, as cited in Mwaanga \& Adeosun, 2017) who point to "vertical partnerships" in which "northern experts speak on behalf of the south" (pp. 58-59). This phenomenon, Richard Giulianotti (2004, p. 22) writes, is characterized as the "cultural legacy of colonialism" wherein, as Tula Brannelly (2016) argues, the presumption of expertise is analogous with the assumption of a "dominant and colonising position ... which fails to recognize the expertise and worldview of colonised societies" (p. 4). Cross-cultural approaches are a useful response to ethnocentric discourses on knowledge production (Beiser, 2003; Sullivan \& Cottone, 2010) because of their potential to contextualize researcher interpretations and situate knowledge within local communities. However, while a cross-cultural approach may help researchers "to reconsider conceptualizations that appear to be universal yet are actually based in Western standards and perspective" (Sullivan \& Cottone, 2010, p. 360), we are keen in future work to use the Jamaican context as a starting point for cross-cultural conversation.

\section{Conclusion}

Intergenerational learning programs that are rooted in a social investment perspective are driven by a dynamic set of overlapping interests that are both complementary and conflicting, particularly for programs in school 
settings, where there are usually four types of participants: the practitioner, school staff, parents, and children. Similar to Jürgen Habermas (1987), our findings suggest that all partners involved in the experience are equally important and should be treated as such. They each tacitly create, exchange, and embody ideas, beliefs, and perceptions about right ways of being, learning, and interacting, and these must be carefully negotiated prior to and during the program implementation. We also acknowledge that, rather than viewing discordant lifeworlds as deficient, the practitioners ought to see an opportunity to build and support rich, authentic learning experiences which all participants can benefit from. We refer to this as the need to balance power. By eschewing a top-down transmission of knowledge in favour of one that is more open and democratic, all partners are empowered to learn from each other while simultaneously increasing knowledge and strengthening skills. At the same time, we caution against discourses that minimize the role of facilitators; instead we reconceptualize the facilitator role as a form of supportive power which, in line with Wainwright and Marandet (2013), should be acknowledged as a potentially positive force that does not require removal, dismissal, or minimization of power. 


\section{References}

Argent, K. (2007). Every child matters: Change for parents/carers and families? Can schools work with families to promote knowledge and understanding of government expectations? Education 3-13, 35(3), 295-303. https://doi.org/10.1080/03004270701467317

Ashworth, E., \& Bourelle, T. (2014). Utilizing critical service-learning pedagogy in the online classroom: Promoting social justice and effecting change? Currents in Teaching \& Learning, 7(1), 64-79.

Auerbach, E. R. (1989). Toward a social-contextual approach to family literacy. Harvard Educational Review, 59(2), 165-181. (ERIC Document Reproduction Service No. EJ393180).

Bailey, C., Robinson, T., \& Coore-Desai, C. (2014). Corporal punishment in the Caribbean: Attitudes and practices. Social \& Economic Studies, 63(3/4), 207-234. Retrieved from https://www.researchgate.net/publication/283658399_Corporal_Punishment_in_the_ Caribbean_Attitudes_and_Practices

Baker, A., Kolb, D., \& Jensen, P. (2002). Conversational learning: An experiential approach to knowledge creation. Westport, CT: Quorum.

Barillas, M. R. (2000). Literacy at home: Honoring parent voices through writing. The Reading Teacher, 54(3), 302-308. (ERIC Document Reproduction Service No. EJ617772).

Beiser, M. (2003). Why should researchers care about culture? Canadian Journal of Psychiatry, 48, 154-160. https://doi.org/10.1177\% 2F070674370304800303

Bengtsson, S., \& Barakat, B. (2016). Education \& the sustainable development goals. Retrieved from http://unesdoc.unesco.org/ images/0024/002455/245580E.pdf

Black, M. C. (2007). Family literacy. Education Today, 19, 21-23.

Brannelly, T. (2016). Decolonising research practices with the ethics of care. Nursing Ethics, 23(1), 4-6. https://doi. org/10.1177\%2F0969733015624297

Brassett-Grundy, A. J. (2001). Parental perspectives of family learning-Research summary. British Educational Research Association Annual Conference, University of Leeds, September 13-15. Retrieved from http://www.leeds.ac.uk/educol/documents/00001917. htm

Braun, V., \& Clarke, V. (2006). Using thematic analysis in psychology, Qualitative Research in Psychology, 3, 77-101. http://dx.doi. org/10.1191/1478088706qp063oa

Brown, A. (2011). Consciousness-raising or eyebrow-raising? Reading urban fiction with high school students in Freirean cultural circles. Perspectives on Urban Education, 9(1), 1-12. Retrieved from https://files.eric.ed.gov/fulltext/EJ957121.pdf

Brown, B. L. (1998). Family literacy: Respecting family ways. Columbus, OH: ERIC Clearinghouse on Adult, Career, and Vocational Education. Retrieved from http://www.edpsycinteractive.org/files/famliteracy.html

Bryan, J., \& Henry, L. (2012). A model for building school-family-community partnerships: Principles and process. Journal of Counselling and Development, 90(4), 408-420. https://doi.org/10.1002/j.1556-6676.2012.00052.x

Bryk, A., \& Schneider, B. (2002). Trust in schools: A core resource for improvement. New York, NY: Russell Sage Foundation.

Burnard, P., Craft, A., Cremin, T., Duffy, B., Hanson, R., Keene, J., Haynes, L., \& Burns, D. (2006). Documenting "possibility thinking": A journey of collaborative enquiry. International Journal of Early Years Education, 14(3), 243-262. https://doi. org/10.1080/09669760600880001

Cartmel, J., Radford, K., Dawson, C., Fitzgerald, A., \& Vecchio, N. (2018). Developing an evidenced based intergenerational pedagogy in Australia. Journal of Intergenerational Relationships, 16(1-2), 64-85. https://doi.org/10.1080/15350770.2018.1404412

Dixon, K., \& Lewis, K. (2008). Parents, teachers, and early literacy: The perceptions of parents and teachers of the roles they should play in developing children's early literacy. In S. Desmond \& M. Elfert (Eds.), Family literacy experiences from Africa and around the world. Cape Town, South Africa: UNESCO Institute for Lifelong Learning. Retrieved from https://files.eric.ed.gov/fulltext/ ED540499.pdf 
Elish-Piper, L (2000). An analysis of the social-contextual responsiveness of adult education in urban family literacy programs: Trends, obstacles and solutions, Reading Research and Instruction, 39(3), 184-200. https://doi.org/10.1080/19388070009558321

Epstein, J. (2010). School/family/community partnerships: Caring for the children we share. Phi Delta Kappan Magazine, 92(3), 81-96. https://doi.org/10.1177\%2F003172171009200326

Foucault, M. (1991). Governmentality. In G. Burchell, C. Gordon, \& P. Miller (Eds.), The Foucault effect: Studies in governmentality (pp. 87-104). Hemel Hempstead, UK: Harvester Wheatsheaf.

Frank, A. W. (2000). Notes on Habermas: Lifeworld and system. Retrieved from http://people.ucalgary.ca/ frank/habermas.html

Freire, P. (1970). Pedagogy of the oppressed. New York, NY: Herter \& Herter.

Friedman, W., Kremer, M., Miguel, E., \& Thornton, R. (2011). Education as liberation. National Bureau of Economic Research Working Paper No. 16939. Retrieved from https://www.nber.org/papers/w16939

Giulianotti, R. (2004). Human rights, globalisation, and sentimental education: The case of sport. Sport in Society, 7(3), 355-369. https:// doi.org/10.1080/1743043042000291686

Goodall, J., \& Montgomery, C. (2014). Parental involvement to parental engagement: A continuum. Educational Review, 66(4), 399-410. http://dx.doi.org/10.1080/00131911.2013.781576

Habermas, J. (1984). The theory of communicative action: Reason and the rationalization of society (Vol. 1). London, UK: Heinemann.

Habermas, J. (1987). The theory of communicative action: The critique of functionalist reason (Vol. 2). London, UK: Heinemann.

Haigh, N. (2005). Everyday conversation as a context for professional learning and development. International Journal for Academic Development, 10(1), 3-16. https://doi.org/10.1080/13601440500099969

Hall, B. (2014). No more enclosures: knowledge democracy and social transformation. Retrieved from https://www.opendemocracy.net/ transformation/budd-hall-rajesh-tandon/no-more-enclosures-knowledge-democracy-and-social-transformat.

Hamilton, M., \& Burgess, A. (2011). Back to the future? Functional literacy and the new skills agenda. Retrieved from http://eprints.lancs. ac.uk/66608/

Hannon, P., \& Bird, V. (2004). Family literacy in England: Theory, practice, research, and policy. In B. H. Wasik (Ed.), Handbook offamily literacy (pp. 23-39). Mahwah, NJ: Lawrence Erlbaum.

Hardacre, C. (2011). Pay no attention to that man behind the curtain. An action research project considering the use of task-based learning in the adult literacy classroom. Through the looking glass: Reflective research in post compulsory education (pp. 97-103). Preston, UK: UCLAN.

Hardacre, C. (2017). Promoting young people’s well-being through empowerment and agency. In K. Stuart \& L. Maynard (Eds.), Empowerment and agency (pp. 138-152). London, UK: Routledge.

Harris, A., \& Goodall, J. (2008). Do parents know they matter? Engaging all parents in learning. Educational Research, 50(3), $277-289$. https://doi.org/10.1080/00131880802309424

Hermanowicz, J. C. (2002). The great interview: 25 strategies for studying people in bed. Qualitative Sociology, 25(4), 479-499. https:// doi.org/10.1023/A:1021062932081

Herz, B., \& Sperling, G. B. (2004). What works in girls' education: Evidence and policies from the developing world. New York, NY: Council on Foreign Relations.

Heydon, L., \& Reilly, J. (2007). Professional development for family learning programmes: A rationale and outline curriculum. Literacy, 41(3), 155-160. https://doi.org/10.1111/j.1467-9345.2007.00471.x

Holloway, S., Brown, G., \& Pimlott-Wilson, H. (2011). Editorial introduction: Geographies of education and aspiration. Children's Geographies, 9, 1-5. https://doi.org/10.1080/14733285.2011.540434 
Hui, F., \& Koplin, M. (2011). The implementation of authentic activities for learning: A case study in finance education. Business Education and Scholarship of Teaching, 5(1), 59-72. Retrieved from https://ro.uow.edu.au/commpapers/1629/

Ilesanmi, O. O. (2009). What is cross-cultural research? International Journal of Psychological Studies, 1(2), 82. http://dx.doi.org/10.5539/ ijps.v1n2p82

Jacobson, E. Degener, S., \& Purcell-Gates, V (2003). Creating authentic materials for the adult literacy classroom: A handbook for practitioners. Cambridge, MA: World Education.

Kinkead-Clark, Z., \& Hardacre, C. (2017). Using cross-cultural conversations to contextualize understandings of play: A multinational study. Early Child Development and Care, 187(5-6), 935-945. https://doi.org/10.1080/03004430.2016.1244673

Kwan, P., \& Wong, Y. L. (2016). Parental involvement in schools and class inequality in education: Some recent findings from Hong Kong. International Journal of Pedagogies and Learning, 11(2), 91-102. https://doi.org/10.1080/22040552.2016.1227250

Lamb, P. (2009). The impact of learning as a family: A model for the 21st century. Leicester, UK: National Institute of Adult Continuing Education.

Lawrence-Lightfoot, S. (2004). The essential conversation: What parents and teachers can learn from each other. New York, NY: Ballantine Books.

Learning and Work Institute. (2019). Family learning. Retrieved from http://www.learningandwork.org.uk/our-work/life-and-society/familylearning/

Leeds City Council. (2017). Employment and skills adult learning provision 2017/18 project brief. Retrieved from https://www.leeds.gov.uk/ docs/Adult\%20Learning\%202018-19\%20Project\%20Brief\%20-\%20FINAL.pdf

Levermore, R., \& Beacom, A., (2009). Sport and international development. Basingstoke, UK: Palgrave Macmillan.

Levine, R., Lloyd, C., Greene, M., \& Grown, C. (2008). Girls count: A global investment and action agenda. Washington, DC: Center for Global Development.

Lexmond, J., Bazalgette, L., \& Margo, J. (2011). The home front. London, UK: Demos. Retrieved from https://www.demos.co.uk/files/ Home_Front_-_web.pdf?1295005094

Lombardi, M. M. (2007). Authentic learning for the 21st century: An overview. Retrieved from https://library.educause.edu/-/media/files/ library/2007/1/eli3009-pdf.pdf

Loughrey, D., \& Woods, C. (2010). Sparking the imagination: Creative experts working collaboratively with children, teachers and parents to enhance educational opportunities. Support for Learning, 25(2), 81-90. https://doi.org/10.1111/j.1467-9604.2010.01444.x

Luguetti, C., \& Oliver, K. L. (2017). "Getting more comfortable in an uncomfortable space": Learning to become an activist researcher in a socially vulnerable sport context. Sport, Education, and Society, 1-13. https://doi.org/10.1080/13573322.2017.1290598

Maina, F. W. (2004). Authentic learning: Perspectives from contemporary educators. Journal of Authentic Learning, 1(1), 1-8. Retrieved from https://dspace.sunyconnect.suny.edu/handle/1951/389

McDowell, L. (2004). Work, workfare, work/life balance, and an ethic of care. Progress in Human Geography, 28, 145-165. https://doi. org/10.1191\%2F0309132504ph4780a

Moriarty, V. (2001). Family learning programmes: An investigation of parental perceptions, social capital and social inclusion. Educate, $1(1), 85-103$.

Mwaanga, O., \& Adeosun, K. (2017). Decolonisation in practice: A case study of the Kicking AIDS Out programme in Jamaica. Journal of Sport for Development, 5(9), 58-69. Retrieved from https://www.researchgate.net/publication/323691580_Decolonisation_in_ practice_A_case_study_of_the_Kicking_AIDS_Out_programme_in_Jamaica

National Institute of Adult Continuing Education. (2013). Family learning works: The inquiry into family learning in England and Wales. Leicester, UK: Author. 
Pahl, K., \& Kelly, S. (2005). Family literacy as a third space between home and school: Some case studies of practice. Literacy, 91-96. https://doi.org/10.1111/j.1741-4350.2005.00406.x

Raco, M. (2009). From expectations to aspirations: State modernisation, urban policy, and the existential politics of welfare in the UK. Political Geography, 28, 436-444. http://dx.doi.org/10.1016\%2Fj.polgeo.2009.10.009

Rao, N., Sun, J., Wong, J. M. S., Weekes, B., Ip, P., Shaeffer, S. Young, M., Bray, M. Chen, E., \& Lee, D. (2014). Early childhood development and cognitive development in developing countries: A rigorous literature review. Hong Kong: Department for International Development.

Rocha-Schmid, E (2010). Participatory pedagogy for empowerment: A critical discourse analysis of teacher parents' interactions in a family literacy course in London. International Journal of Lifelong Education, 29, 343-358. https://doi.org/10.1080/02601371003700659

Sangster, P., Stone, K., \& Anderson, C. (2013). Transformative professional learning: Embedding critical literacies in the classroom. Professional Development in Education, 39(5), 615-637. https://doi.org/10.1080/19415257.2012.751617

Schweisfurth, M. (2014). Learner-centred pedagogy: Towards a post-2015 agenda for teaching and learning. International Journal of Educational Development, 40, 259-266. http://dx.doi.org/10.1016/j.ijedudev.2014.10.011

Senge, P. (1994). The fifth discipline fieldbook: Strategies and tools for building a learning organization. London, UK: Nicholas Brealey.

Simpson, D., \& Cieslik, M. (2002). Education action zones, empowerment, and parents. Educational Research, 44(2), 111-128. https:// doi.org/10.1080/00131880210135269

Suhonen, R., Saarikoski, M., \& Leino-Kilpi, H. (2009). Cross-cultural nursing research. International Journal of Nursing Studies, 46(4), 593-602. https://doi.org/10.1016/j.ijnurstu.2008.09.006

Sullivan, C., \& Cottone, R. (2010). Emergent characteristics of effective cross-cultural research: A review of the literature. Journal of Counseling \& Development, 88(3), 357-362. https://doi.org/10.1002/j.1556-6678.2010.tb00033.x

Tanaka-Matsumi, J. (2001). Abnormal psychology and culture. In D. Matsumoto (Ed.), The handbook of culture and psychology (pp. 265-286). New York, NY: Oxford University Press.

Timmons, K., \& Pelletier, J. (2014). Understanding the importance of parent learning in a school-based family literacy programme. Journal of Early Childhood Literacy, 15(4), 510-532. https://doi.org/10.1177\%2F1468798414552511

Vincent, C. \& Warren, S. (1998). Becoming a "better" parent? Motherhood, education, and transition. British Journal of Sociology of Education, 19, 177-193. https://doi.org/10.1080/0142569980190202

Wainwright, E., \& Marandet, E. (2011). Geographies of family learning and aspirations of belonging. Children's Geographies, 9(1), 95-109. https://doi.org/10.1080/14733285.2011.540442

Wainwright, E., \& Marandet, E. (2013). Family learning and the socio-spatial practice of "supportive" power. British Journal of Sociology of Education, 3, 504-524. https://doi.org/10.1080/01425692.2012.723870

Wainwright, E., \& Marandet, E. (2017). Education, parenting, and family: The social geographies of family learning. British Educational Research Journal, 43(2), 213-229. https://doi.org/10.1002/berj.3262

West, L. (2005). The radical challenge of family learning. Adults Learning, 16(6), 11-13.

Widenfelt, B., Treffers, M., Beurs, P., Siebelink, D., \& Koudijs, A. (2005). Translation and cross-cultural adaptation of assessment instruments used in psychological research with children and families. Clinical Child and Family Psychology Review, 8(2), 135147. https://doi.org/10.1007/s10567-005-4752-1

Wolfinger, N. H. (2002). On writing field-notes: Collection strategies and background expectancies. Qualitative Research, 2, 85-95. Retrieved from https://entwicklungspolitik.uni-hohenheim.de/uploads/media/Day_2__Reading_text_4_02.pdf 